\title{
The granulating process as an effective way to increase demand for high calcium fly ash of a thermal power plant
}

\author{
I. Domanskaya, F. Kapustin, V. Ufimtsev \& V. Oleynik \\ Institute of Materials Science and Metallurgy, \\ Ural Federal University, Russia
}

\begin{abstract}
High calcium fly ash (HCFA), formed in the process of burning of brown coal and some types of combustible shale is the most ecologically dangerous among the solid waste of thermal power plants (TPP). The free calcium oxide $\left(\mathrm{CaO}_{\text {free }}\right)$ present in the HCFA complicates the work of the ash-handling system and increases the risk of allocation of alkaline effluent from the dumps. Disposal of a dry selection HCFA in the production of construction materials is problematic as hardening of the ash stone often results in extension. To reduce the environmental risks in the TPP and increase recycling of HCFA a preliminary its (HCFA) granulation is suggested instead of the traditional hydraulic ash removal system. The methods of HCFA granulation were investigated by using waste products of Kansk-Achinsk coal. Granular ashes, depending on the $\mathrm{CaO}_{\text {free }}$ content are suggested to use for the replacement of natural aggregates for concrete, to obtain cement clinker by means of high-speed firing of granules in a sintering machine as active mineral additives for mixed binding materials.

Keywords: high calcium fly ash, free calcium oxide, granulation, granular ashes, aggregates, concrete, cement clinker.
\end{abstract}

\section{Introduction}

In spite of the fact that renewable sources of energy are available, coal-burning power fails to lose its importance and actuality. The increase of coal consumption in many countries as one of the most accessible types of power resources is pointed out; new technologies as to its burning are worked out resulting in effluents of sulphur and nitrogen oxides (oxyfuel capture method, 
reburning process, etc.) As this takes place the problem of solid waste utilization, namely: coal fly-ashes and fuel slag is still exists. In some countries of the European Community the share of fuel ash slag used reaches $90 \%$, but it does not exceed $15 \%$ in Russia. At TPP in Russia the main mass of solid waste is removed by hydraulic deposition of dumps. Ash dumps occupy considerable areas and is one of the most serious sources of environmental pollution. The ecological problems become redoubling (aggravating) in case of HCFA being formed on the burning of the brown coals on the one hand and some types of combustible shale on the other one. The burning coals and combustible shale can contain from $10 \%$ to $50 \%$ of $\mathrm{CaO}$ in its composition including up to $30 \%$ in free not chemically bound state $\left(\mathrm{CaO}_{\text {free }}\right)$. The ability of these materials to soften and harden is the reason of the durable deposits inside pipe-lines causing emergency situations. The solution at issue for this problem is made possible through the utilization of dry selection. However, taking into account that annual yield of ash slays at the Russian TPP measures tens of millions of tons the complete utilization of them presents no possibilities so far. Therefore, nowadays the optimum method (process) of the problem solving is to organize the temporary storage of the unused part of dry ash with the maximum possible preserving of its service properties. The present work deals with the problem solution concerning HCFA.

\section{Granulating of high-calcium coal burning power waste proper at TPP is an effective alternative to hydraulic ash removal}

The technology of ecologically safe removal and storage of HCFA with its preliminary granulation was suggested at the Ural Polytechnic Institute (now the Ural Federal University named after the first President of Russia B. Eltsin) in codesigner ship (cooperation) with "Uraltechenegro" and "Rostov Teploproect" department [1]. The HCFA consisting of $\mathrm{CaO}_{\text {free }}$ can be considered as specific technogenic class of binding substances because they exhibit hydraulic activity and harden to form a stone of various strengths. It is obvious that after the HCFA reaction with water in the process of the hydraulic ash removal these binding substances lose their ability to harden and their repeated utilization as independent binding agents is excluded. At the same time due to the hydraulic properties proper they can be granulated without cement additions or other binding substances which are usually used in practice to obtain unburnt ash gravel on the basis of the acid ashes. In accordance with the technology suggested the part of the dry selection ash must be unloaded to the users, and that of unused is converted from the dispersed (powdered) condition into the granular one by means of granulation.

\subsection{The main trends of the granulated high-calcium fly ashes utilization}

Further utilization of the granulated ash product [GAP] utilization obtained from TPP depends on its strength and structure stability as to time. It is established 
that the deformation magnitude of the ash stone is determined by the original ash quality, i.e. the method and burning temperatures of coals, dispersity, $\mathrm{CaO}_{\text {free }}$ and $\mathrm{SO}_{3}$ content in the ash investigated; the type and quantity of the crystalline and amorphous phases and also by its hydration conditions and hardening, namely: the quantity of the water mixing; the occurrence of chemical water soluble additions; the temperature and storage moisture. The mechanism of this process depends on the ratio of the crystallization process of calcium hydroxide, ettringite, and hydrosilicates strengthening the structure during the later stages of hydration $[2,3]$. Depending on the GAP quality it may be used as the filler (aggregate) for concrete products, as the raw material to produce binding materials and as unused part, i.e. stored in special granule storages which can be unloaded to the customers as far as possible (Fig. 1).

\subsubsection{Unburnt ash gravel}

The optimum conditions of HCFA granulation by using the laboratory plate granulator and the possibility of its utilization as concrete filler for construction works have been studied and investigated by using as an example 10 samples of HCFA consisting of $2.2 \%$ to $8,5 \%$. $\mathrm{CaO}_{\text {free }}$ obtained by burning the brown coal of Siberia in different furnaces working with solid and liquid slag removal, with circular fluidized bed. It is established that HCFA containing up to 5\% of $\mathrm{CaO}_{\text {free }}$ can be used as unburnt ash gravel without the additional treatment of granules. It is expedient to partially hydrate them preliminary to reduce the destructive preliminary potential of ashes containing more than $5 \%$ of $\mathrm{CaO}_{\text {free }}$ [4]. The mixing time of ashes with water must be limited up to 5-10 minutes otherwise water requirement of the ashes under study increases by 2-3 times and the granules strength decreases by 30-50\% [5]. The ash filler obtained under the optima conditions, depending on the ash type possesses bulk density $700-1200 \mathrm{~kg} / \mathrm{m}^{3}$, strength $10-100 \mathrm{~N} /$ granule. Unburnt ash gravel can be used in the concrete production technology for different purposes including road building.

\subsubsection{Production of fly-ash clinker based on granulated ashes}

By means of drawing through of method the technology of clinker obtaining by using HCFA has been developed. The clinker production by drawing through method is characterized by the two limits: production of raw pellets and their burning. By using the ash of Kansk-Achinsk coal consisting of $24.4 \% \mathrm{CaO}_{\text {free }}$ and $5.6 \%$ residual fuel as an example it had been determined the optimum conditions of the ash granulation providing the yield of the 5-20 mm granule fraction up to $75-95 \%$ with the strength more than $5 \mathrm{~N} /$ granule and thermal heat stability more than $1000^{\circ} \mathrm{C}$. The principal production operations have been developed including dosing moistening nodulizing by means of plate granulator, thermal treatment by using agglomeration machine with $24 \mathrm{~m}^{2}$ useful area. The sequence of phase forming on heating HCFA has been established; the composition of primary and final compounds and the interval of their stability have been revealed. The clinker yield on burning ash granules was $93-96 \%$ and the heat rate from the external heat-transfer medium is about $1350 \mathrm{~kJ} / \mathrm{kg}$. As to clinker it consists of $26 \%$ of nonstoichiometric alite, $23-58 \%$ of $\beta-\mathrm{CaO} \cdot \mathrm{SiO}_{2}$. 


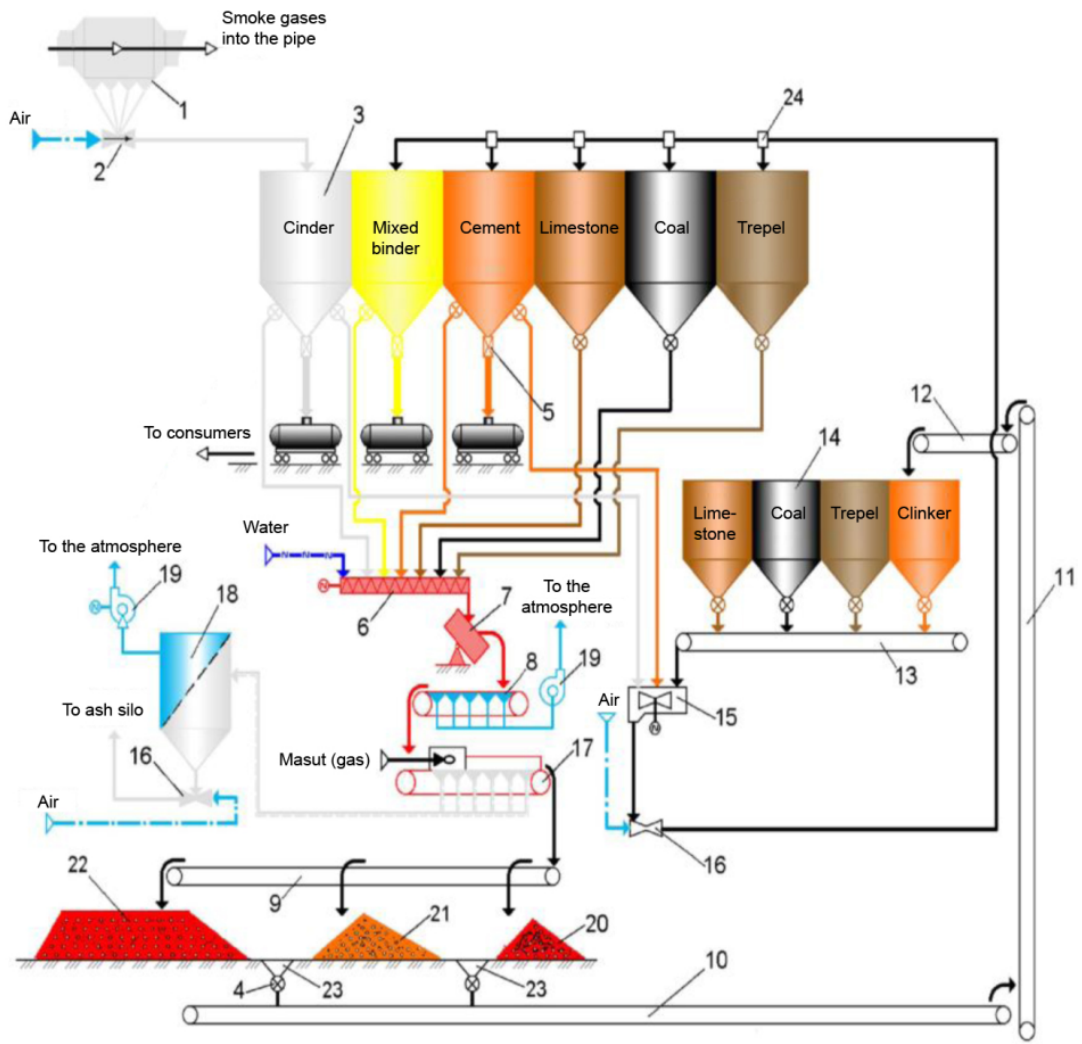

Figure 1: Removal technology of high-calcium ashes by using preliminary granulation: 1 - electrical filter; 2 - electrostatic precipitator; 3 - storage for ash, ground raw materials, prepared binding materials; 4 - measuring hopper, feeder; 5 - loading device; 6 - mixer; 7 - granulator; 8 - conveyor of preliminary strengthening of granules; 9-13 - belt conveyor; 14 - raw materials store; 15 - milling unit; 16 - pneumotransporting machine; 17 - sintering machine; 18 - gas cleaner; 19 - exhauster (exhaust far); 20 - unburnt ash gravel store; 21 - clinker storage; 22 - granules storage; 23 - bunker; 24 - switch.

and $\alpha-\mathrm{CaO} \cdot \mathrm{SiO}_{2}, 10-30 \%$ of calcium aluminates and aluminoferrites of variable composition, up to $6 \%$ of $4 \mathrm{CaO} \cdot \mathrm{Al}_{2} \mathrm{O}_{3} \cdot \mathrm{Fe}_{2} \mathrm{O}_{3}$. The clinker under investigation is characterized with clear-cut finegrained crystallization and considerable defectness of the minerals. The binding agent made of ash clinker with $5 \%$ of gypsum is characterized with quick (rapid) period of setting: beginning from 517 minutes and 11-35 minutes ending. This binding agent is characterized by rapid and stable strength growth: in a day of normal hardening - 6-11 $\mathrm{MPa}$; in 3 days - 14-20 MPa; by 28 days - 30-50MPa; at the age of 180 days - 60- 
$90 \mathrm{MPa}$. The addition of ash belite clinker in the quantity of 3-50\% to PC clinker guarantees the obtaining of rapid - hardening and of high strength mixed binding materials possessing high corrosion resistance and durability, the composition of which are protected by the Certificated of invention Authorship [6].

\subsubsection{Fly-ash clinker as an addition to produce high strength cements}

On the basis of two clinkers, namely: the Portland cement (PC) clinker and fly ash one the composite binders have been studied. The clinker from OAO Suholozhcement has been used as PC clinker, and the high calcium granulated ash containing $24.4 \%$ of $\mathrm{CaO}$ free in the original state burnt up to caking has been used as the fly ash one. The composite binders have been manufactured by combined mixing of the PC clinker and the additions from $3 \%$ to $40 \%$ of the ash clinker and gypsum (Table 1). It was noted that the more quantity of the fly ash clinker addition the less is the mixing time of the compositions to the similar type of dispersity. For example, when $15 \%$ of the ash clinker is added the mixing time is reduced by $8 \%$; when $40 \%$ of the ash clinker is added the mixing time is reduced by $20 \%$. This is explained by its less hardness in comparison with the $\mathrm{PC}$ clinker. Due to the fly-ash clinker addition the water requirement increases on the one hand but the setting time of the cement paste decreases compared to the initial composition on the other one. The presence of the minerals possessing high early hydration activity seems to contribute to the rapid oversaturation of the liquid phase and the earlier crystallization center formation. When the fly-ash clinker additions are available the composite binders activity increases compared to the initial $\mathrm{PC}$ at the age of 3 days by $3-30 \%$, and that of 28 days by $7-20 \%$ accordingly. The composite binder having 3\% of the fly-ash clinker addition has the highest strength. By means of X-rays phase analysis it has been established that the highest activity of the mixed binders during the original time of hardening is determined by higher crystallization of calcium aluminate hydrates and ettringite but during the further period of hardening - be calcium silicate hydrates of low base.

Table 1: The effect of fly-ash clinker additives on cement properties.

\begin{tabular}{|c|c|c|c|c|c|c|c|c|}
\hline \multicolumn{3}{|c|}{$\begin{array}{l}\text { Cement composition by } \\
\text { weight, } \%\end{array}$} & \multicolumn{2}{|c|}{$\begin{array}{l}\text { Time of setting } \\
\text { (hours-minutes) }\end{array}$} & \multicolumn{2}{|c|}{$\begin{array}{c}\text { Compressive } \\
\text { strength, MPa, of } \\
\text { paste samples at the } \\
\text { age of }\end{array}$} & \multirow{2}{*}{$\begin{array}{l}\text { Coefficient of } \\
\text { sulphate } \\
\text { resistance in } \\
\text { the solution of } \\
5 \% \mathrm{MgSO}_{4}\end{array}$} & \multirow{2}{*}{$\begin{array}{l}\text { Coefficient of } \\
\text { frost } \\
\text { resistance } \\
\text { (in } 25 \\
\text { cycles) }\end{array}$} \\
\hline $\begin{array}{c}\mathrm{PC} \\
\text { klinker }\end{array}$ & $\begin{array}{l}\text { Fly ash } \\
\text { klinker }\end{array}$ & $\begin{array}{l}\text { Gip } \\
\text { sum } \\
\text { stone }\end{array}$ & beginning & ending & 3 days & $\begin{array}{c}28 \\
\text { days }\end{array}$ & & \\
\hline 95 & - & 5 & $1-55$ & $4-15$ & 38.2 & 84.5 & 0.87 & 0.86 \\
\hline 92 & 3 & 5 & $0-45$ & $1-25$ & 51.0 & 102.9 & 0.85 & 0.92 \\
\hline 80 & 15 & 5 & $0-26$ & $0-40$ & 44.8 & 97.1 & 0.91 & 0.98 \\
\hline 66 & 30 & 4 & $0-15$ & $0-26$ & 43.6 & 94.3 & 0.97 & 0.89 \\
\hline 57 & 40 & 3 & $0-10$ & $0-20$ & 39.4 & 90.5 & 0.95 & 0.87 \\
\hline
\end{tabular}




\subsubsection{Granulated high-calcium fly ashes in concrete structure}

The investigations have been also carried out as to the application of the granulated fly ash sand (GFAS) consisting of $2.5 \% \mathrm{CaO}_{\text {free }}$ at the age of 28 days and after 5 years of weather storage in the concrete content. The bulk density of the initial granules was $920 \mathrm{~kg} / \mathrm{m}^{3}$ and after 5 years $-1130 \mathrm{~kg} / \mathrm{m}^{3}$ water adsorption 21 and $12 \%$ accordingly, yield strength on compression in cylinder 0.8 and 5.0 MPa. The granules batches investigations meet GOST 9757 requirement and correspond to strength brand P35 for the initial granules and P200 - after weather (air) storage. GFAS was used as an aggregate for the concretes of both ordinary hardening and cured in steam ones at the temperature $95^{\circ} \mathrm{C}$ at the $2+6$ rate with the preliminary cure before steam curing not less than 3 hours. One part of the conditioned granules was subjected to crushing by using the role crusher to obtain porous sand with 2.8 gradation factor which was introduced into the concrete mix as the fine aggregate. Another part of the conditioned granules was crushed to $350 \mathrm{~m}^{2} / \mathrm{kg}$ of specific surface to reduce cement consumption. For comparison, quartz sand with the gradation factor equal to 2.0 was used side by side with the fly ash one (Table 2).

Table 2: Concretes mixes on the basis of granulated fly ash.

\begin{tabular}{|c|c|c|c|c|c|c|c|}
\hline \multirow{3}{*}{$\begin{array}{l}\text { Mix } \\
\text { number }\end{array}$} & \multicolumn{7}{|c|}{ Materials consumption, $\mathrm{kg} / \mathrm{m}^{3}$} \\
\hline & \multirow[t]{2}{*}{ cement } & \multirow{2}{*}{$\begin{array}{l}\text { GFAS } \\
\text { crushed }\end{array}$} & \multicolumn{2}{|c|}{ GFAS } & \multirow{2}{*}{$\begin{array}{l}\text { quartz } \\
\text { sand }\end{array}$} & \multirow{2}{*}{$\begin{array}{l}\text { GFAS } \\
\text { sand }\end{array}$} & \multirow[t]{2}{*}{ water } \\
\hline & & & P200 & P35 & & & \\
\hline 1 & 350 & 100 & 940 & - & 640 & - & 135 \\
\hline 2 & 280 & 170 & 940 & - & 600 & - & 100 \\
\hline 3 & 200 & 200 & - & 740 & - & 220 & 230 \\
\hline 4 & 100 & 300 & - & 740 & - & 330 & 225 \\
\hline
\end{tabular}

The heavy-weight concretes of M200-300 grades with $2000-2200 \mathrm{~kg} / \mathrm{m}^{3}$ density were obtained by using GFAS and quartz sand and 300-400 cement consumption. The light-weight concretes of M 35-100 grades with cement consumption $100-200 \mathrm{~kg} / \mathrm{m}^{3}$ have been obtained by complex using of both the ash granules and the products of their crushing (Table 3 ).

\subsection{The results of the dump storage modelling of the granulated high-calcium fly-ash}

The batch of granules of 10-15 mm fraction obtained from the HCFA containing $11.5 \%$ of $\mathrm{CaO}_{\text {free }}$ was put into the dump modeled for the atmospheric storage in the quantity of $50 \mathrm{~kg}$ beginning from the April month. The modeled dump is a special device $1.2 \mathrm{~m}$ height consisting of 5 separate cylinders - vessels installed one over another; on the bottom of the first top cylinders there are the holes for free water filtration. Due to the seals between them all the process of the mass exchange with the environment flow through the surface layer in this device. 
Table 3: Characteristics of the concretes consisting of granulated ash sands.

\begin{tabular}{|c|c|c|c|c|c|c|}
\hline \multirow[t]{2}{*}{$\begin{array}{c}\text { Mix } \\
\text { number }\end{array}$} & \multicolumn{2}{|c|}{$\begin{array}{c}\text { Flow- } \\
\text { ability/stiffness of } \\
\text { concrete mix }\end{array}$} & \multirow{2}{*}{$\begin{array}{l}\text { Moulding } \\
\text { conditions }\end{array}$} & \multirow{2}{*}{$\begin{array}{l}\text { Density, } \\
\mathrm{kg} / \mathrm{m}^{3}\end{array}$} & \multicolumn{2}{|c|}{$\begin{array}{c}\text { Compressive strength, } \\
\mathrm{MPa}\end{array}$} \\
\hline & $\mathrm{cm}$ & S & & & $\begin{array}{c}\text { after thermal } \\
\text { treatment }\end{array}$ & $\begin{array}{l}\text { at age of } \\
28 \text { days }\end{array}$ \\
\hline 1 & - & $15-20$ & $\begin{array}{l}\text { Vibration with } \\
\text { counter-weight } \\
60 \mathrm{~s}\end{array}$ & 2200 & 24.3 & 34.7 \\
\hline 2 & - & $15-20$ & The same & 2000 & 21.0 & 26.3 \\
\hline 3 & $4-6$ & - & Vibration $60 \mathrm{~s}$ & 1600 & 11.1 & 13.9 \\
\hline 4 & $4-6$ & - & The same & 1450 & 3.3 & 4.7 \\
\hline
\end{tabular}

It was established that within the first 6 months of storage (April-September) the additional reactions of $\mathrm{CaO}_{\text {free }}$ hydration and glassy phase hydrolysis take place due to the moisture-exchange conditions at the expense of adsorption and evaporation of rain precipitations. The processes in question are especially active in the dump surface layer $300 \mathrm{~mm}$ deep. These processes are accompanied with granules strengthening, porosity and water-absorption reduction, decreasing $\mathrm{CaO}_{\text {free }}$ content by 1.5-5 times, depending on the dump horizon [7]. Further observation during many years and periodical testing of granules have shown that hydrate phases formed have the tendency to transform into less dried forms as a result their carbonization, e.g.:

$$
\begin{aligned}
& 2 \mathrm{CaO} \cdot \mathrm{SiO}_{2} \cdot \mathrm{H}_{2} \mathrm{O}+\mathrm{Ca}(\mathrm{OH})_{2}+\mathrm{CO}_{2} \rightarrow \mathrm{CaOSiO}{ }_{2} \cdot \mathrm{H}_{2} \mathrm{O}+\mathrm{CaCO}_{3}+\mathrm{CO}_{2} \\
& \rightarrow \mathrm{CaCO}_{3}+\mathrm{SiO}_{2} \cdot \mathrm{nH}_{2} \mathrm{O}
\end{aligned}
$$

Thus, the tendency of the ash stone to form structure is caused by the forming of the most thermodynamically stable compounds and is subjected to the universal geological nature transformation of the earth crust including the "weathering" processes. After 20 years of the atmospheric storage approximately $50 \%$ of the granulated ash product (GAP) looked like sand with 2-5 mm particle size. When investigating building-technical properties of GAP it was revealed that it can be used as coarse and fine aggregate for concrete and mortars. One should point out that the experiment of dump storage carried out had confirmed the principal possibility to organize the storing of granulated ashes in dump conditions without any drains. This is explained by the fact that the granulated ashes layer can not only leak, but to hold rain water precipitation, too and also to evaporate them from the dump surface. The experiment carried out has resulted in the initial data to calculate the necessary height of the dump increase excluding the appearance of the outflows. 


\section{References}

[1] Author's Certificate (Pat) № 998818 (USSR) System of high-calcium ash slags remoxal / V.L. Vishnya, R.N. Volkova, A.N. Viner, V.M. Uphimtsev. Bulletin of Inventions. Published 25 Feb. 1983.

[2] Domanskaya I.K., Oleinik V.N. High-calcium fly ash: forming of composition and hydraulic activity. Ibausil 16. Internationale Baustofftagung.- Weimar, pp. 1-1071-1-1079, 2006.

[3] Domanskaya I.K., Oleinik V.N. Phase composition and mechanism of hardening of high-calcium fly-ash. Ibausil 17. Internationale Baustofftagung.- Weimar, pp. 1-0817-1-0822, 2009.

[4] Author's Certificate №1691345 (USSR). Method of obtaining unburnt gravel made of high-calcium ashes / V.M. Uphimtsev, I.K. Domanskaya, R.V. Yaroslavtseva. Published 15 Nov., 1991.

[5] Domanskaya I.K., Oleinik V.N. Physico-chemical features of the artificial aggregate production on the basis of high-calcium fly ashes. Ibausil 18. Internationale Baustofftagung. Weimar, (Band 2), pp. 0668-0675, 2012.

[6] Author's Certificate №1794911 (USSR). Binding agent/ F.L. Kapustin, M.N. Kaibicheva, B.A. Piyachev. Published 15 Feb. 1993.

[7] Uphimtsev V.M., Kaibicheva M.N., Domanskaya I.K., Kapustin F.L. Change properties of granulated fly-ash and their impact to the environment in atmospheric conditions. The energy construction. № 6. pp. 78-79, 1987. 